УДК 334.7:004.7: 658.1

Гевко В.Л., к.е.н., доцент, докторант

Тернопільський національний технічний університет ім. І. Пулюя

\title{
СТРАТЕГІЧНІ ІМПЕРАТИВИ УПРАВЛІННЯ ПІДПРИСМСТВАМИ МЕРЕЖЕВИХ СТРУКТУР: ТЕОРЕТИЧНА ПЛОЩИНА ТА ПРАКТИЧНИЙ ВИМІР СУЧАСНОГО БІЗНЕС-СЕРЕДОВИЩА
}

\begin{abstract}
Проведено комплексне дослідження стратегічних імперативів управління підприємств мережевих структур в контексті теоретичних аспектів та адаптації практичної компоненти. Доведено, що у механізмі управління підприємств мережевих структур, ключовими є функції координації, організації та планування, функція мотивації на інституціональному рівні, що вирішує одну з найскладніших проблем - підвищення рівня продуктивності праці. Обгрунтовано, що метою функціонування мережевих структур вважають впровадження позитивних екстерналій і забезпечення умов їх відтворення в розширеному масштабі. Слід зазначити, що існує три глобальних напрямки маркетингової стратегії підприємств мережевих структур: сегментація, диверсифікація та інтернаціоналізація.

Ключові слова: підприємства мережевих структур, стратегічні імперативи управління, мережева взаємодія, позитивні екстерналії, маркетингова стратегія.
\end{abstract}

Gevko V.

\section{CTRATIC IMPROVEMENTS OF MANAGEMENT BY ENTERPRISES OF NETWORK STRUCTURES: THEORETICAL PLACE AND PRACTICAL MEASUREMENT OF MODERN BUSINESS ENVIRONMENT}

The complex research of strategic imperatives of management enterprises at network structures in the context of theoretical aspects and adaptation of the practical component is carried out. It is proved that in the mechanism of management of enterprises at network structures key functions of coordination, organization and planning, function of motivation at the institutional level, which solves one of the most difficult problems increase of productivity level. It is substantiated that the purpose of functioning at network structures is the introduction of positive externalities and providing conditions for their reproduction on an expanded scale. It should be noted that there are three global directions of the marketing strategy enterprises at network structures: segmentation, diversification and internationalization.

Key words: enterprises of network structures, strategic imperatives of management, network interaction, positive externalities, marketing strategy.

Гевко В.

\section{СТРАТЕГИЧЕСКАЯ ИМПЕРАТИВЫ УПРАВЛЕНИЕ ПРЕДПРИЯТИЯМИ СЕТЕВЫХ СТРУКТУР: ТЕОРЕТИЧЕСКОЙ ПЛОСКОСТИ И ПРАКТИЧЕСКОЕ ИЗМЕРЕНИЕ СОВРЕМЕННОЙ БИЗНЕС-СРЕДЕ}

Проведено комплексное исследование стратегическое императивов управления предприятий сетевых структур в контексте теоретических аспектов и адаптации практической компоненты. Доказано, что в механизме управления предприятий сетевых структур, ключевыми являются функции координации, организации и планирования, функция мотивации на институциональном уровне, решает одну из самых сложных проблем - повышение уровня производительности труда. Обосновано, что целью функционирования сетевых структур считают внедрение положительных экстерналий и обеспечения условий их воспроизводства в расширенном масштабе. Следует отметить, что существует три глобальных направления маркетинговой стратегии предприятий сетевых структур: сегментация, диверсификация и интернационализация.

Ключевые слова: предприятия сетевых структур, стратегическое императивы управления, сетевое взаимодействие, положительные экстерналии, маркетинговая стратегия.

Постановка проблеми у загальному вигляді i ï̈ зв'язок 3 важливими науковими та практичними завданнями. Міжнародний досвід показує, що здатність сформувати дієвий механізм реалізації стратегії $\epsilon$ найважливішим фактором ефективного функціонування та стабільного розвитку сучасних мережевих структур. 
При цьому будь-які зміни містять у собі протиріччя між прагненням підприємств мережевих структур як економічної системи зберегти стабільність, з одного боку, i необхідністю ii постійного розвитку - 3 іншого. Тому для підтримки стійкої конкурентної переваги підприємств мережевих структур обов'язково повинні враховувати імперативи стратегічного управління, які $\epsilon$ актуальними для досліджуваних підприємств. Отже, наукове обгрунтування імперативів стратегічного управління підприємствами мережевих структур, яке дасть змогу узагальнити головні управлінські акценти $є$ важливим питанням, що створює широку науково-дискусійну платформу.

Аналіз останніх досліджень, у яких започатковано вирішення проблеми. Вагомий внесок у дослідження стратегічних імперативів підприємств мережевих структур зробили провідні вітчизняні науковці такі як С. Гриценко, Г. Дмитренко, О. Вівчар, О. Єрмакова, Т. Заславська, Г. Колодко, В. Кириченко, Т. Максименко, С. Оборська, Ю. Пахомов, Р. Ривкіна, 3. Шершньова, Е. Шарапова, В. Усачева, К. Франкич, Г. Хаєт та інш.

Цілі статті. Метою статті є обгрунтування стратегічних імперативів управління підприємств мережевих структур в контексті теоретичних аспектів та адаптації практичної компоненти. На основі чого досліджено диференціацію стратегій функціонування системи підприємницьких структур у сучасному бізнес-середовищі.

Виклад основного матеріалу дослідження 3 повним обгрунтуванням отриманих наукових результатів. На основі проведених досліджень встановлено, що у сучасних умовах функціонування можна виділити два головні акценти, які повинні стати релевантною управлінською реакцією підприємств мережевих структур на трансформації у бізнес-середовищі. На основі проведених досліджень встановлено. Поперше, сучасні умови характеризуються постійним збільшенням швидкості змін у бізнесі, а саме: підвищенням оперативності управління бізнес-процесами, зростанням динаміки способу життя споживачів і їх запитів під впливом зростаючої інформаційної доступності. Швидкість зростання якості продукції та удосконалення бізнес-процесів зростатиме й надалі, отже, окрім бізнес-рефлексів мережевим структурам необхідна прогресивна система управління стратегічними змінами. По-друге, 3 прискоренням темпів змін у бізнесі зростає складність виникаючих проблем: складність викликає необхідність вибору; для того, щоб вибір було зроблено швидко й на користь найкращої серед багатьох пропозицій - стимулюються технології; удосконалені технології знову ж підвищують складність. Отже, успіх підприємств мережевих структур залежить від здатності ефективно використовувати ті відмінності, які формують унікальність, а саме - від злагодженої системи стратегічного управління системного розвитку [7].

Так, з практичної точки зору в сучасних умовах на перший план висуваються ідеї, пов'язані 3 управлінням відмінностями, тобто побудова системи стратегічного менеджменту, що вміє розпізнавати і визнавати цінності відмінностей, та володіє важелями ефективного використання цих відмінностей для реалізації цілей підприємств мережевих структур. Вочевидь, успішність будь-якого з досліджуваних підприємств пов'язана не тільки 3 вдало розбудованою організаційною структурою, чіткими зв'язками системи управління, а в першу чергу 3 тим, якою мірою менеджмент мережевих структур здатний ефективно використовувати i трансформувати в синергетичний ефект ті відмінності на рівні елементів системи (тобто індивідів, груп працівників, бізнес-одиниць тощо), які створюють унікальність. Отже, виважена стратегічна орієнтація стає необхідною умовою функціонування усіх мережевих підприємств. Це означає, що для формування бізнес-рефлексів, тобто сформованих способів реагування на зміни зовнішнього середовища, досвід, звичайно, відіграє ключову роль. Стратегічні імперативи управління підприємствами мережевих структур у ключових питаннях повинне носити упереджувальний характер. А успіх такого упередження, як було аргументовано, залежить від його унікальності та інноваційності, тобто такої відмінності, яку важко скопіювати конкурентам. Оскільки досвід передбачає 
певну традиційність або застосування перевірених раніше способів, це може стримувати інноваційні наміри, які зазвичай $є$ більш ризиковими, проте стратегічно виграшними. На основі проведених досліджень відзначаємо, що у загальному розумінні імператив визначається як загальне значуще правило, що вказує на необхідність діяти певним чином. Під імперативами стратегічного управління пропонуємо розуміти вимоги, які слід враховувати підприємства мережевих структур для досягнення встановлених стратегічних цілей. Дані вимоги формуються, переду сім, під впливом сучасних тенденцій у бізнес-середовищі [3, 100].

Звертаємо увагу на те, що у механізмі управління підприємств мережевих структур, ключовими $є$ функції координації, організації та планування, функція мотивації на інституціональному рівні, що вирішує одну з найскладніших проблем - підвищення рівня продуктивності праці. 3 точки зору мотивації, мережеві підприємства мають основну особливість - самовдосконалення.

Метою функціонування мережевих структур вважають впровадження позитивних екстерналій і забезпечення умов їх відтворення в розширеному масштабі. До позитивних екстерналій функціонування мережевої структури вони відносять такі:

- акселерація - здатність учасника мережі, вступаючи у взаємодію 3 іншими контрагентами, отримувати мультиплікаційний ефект на усю мережу через синергетичний вплив та відчувати мережевий ефект одночасно;

- стандартизація - об'єднання суб'єктів, що випробовують вплив зовнішніх ефектів, сприяє формуванню узгоджених вимог і підходів до оцінки впливу ефектів i можливостей їх використання;

- інтерналізація - це перетворення зовнішніх витрат на внутрішні в результаті об'єднання підприємств, які виробляють ті або інші блага;

- інформатизація - можливість швидкого навчання суб'єктів мережевої організації, яка в управлінні розвитком економіки виступає важливим чинником для максимізації використання і широкого розповсюдження позитивних ефектів;

- інтенсифікація - це оптимізація зростаючих витрат з метою підвищення рівня їх окупності продукцією.

Сучасний організаційний підхід до побудови підприємств мережевих структур, що виходить за межі галузі або функціональної сфери, вже достатньо тривалий період проходить випробування в рамках його адаптації в діяльності не тільки міжнародних, а й вітчизняних підприємств. Однак, підприємства мережевих структур порушує низку сформованих управлінських принципів, які для нових організаційних структур ще не уточнені і не випробувані в достатній мірі і тому потребують подальшого дослідження як фундаменту для розвитку даної організаційної форми [3, 225].

На основі проведених досліджень встановлено, що стратегічною метою побудови та функціонування підприємств мережевих структур - сприяння переведення економіки на інноваційний шлях розвитку. Слід відзначити, що другорядними цілями можна назвати: 1) вписатися в контекст світових тенденцій розвитку науки і технологій; 2) спиратися на інституційні та правові рішення, що піднімають на принципово новий рівень взаємини науки, освіти, виробничої сфери і ринку; 3) включати розвинений за основними параметрами інститут інтелектуальної власності, сучасні системи менеджменту, маркетингу, комерціалізації нововведень; 4) вимоги до інноваційної мережі: іï робота повинна базуватися на сучасній методології та інструментах в європейській мережі інноваційних релей-центрів (IRC) [4, 34].

В сучасному бізнес-середовищі основною метою $є$ обгрунтування стратегічного розвитку підприємств мережевих структур. Стратегію можна розглядати, як комплексний план для здійснення місії підприємства. По формі стратегія - це один 3 управлінських документів, що може бути представлений у вигляді графіків, таблиць, описань і т.п. За змістом стратегія - це сукупність дій для досягнення цілей організації. При формуванні стратегії насамперед необхідно врахувати: на якій стадії життєвого циклу перебуває галузь; структуру галузі; сутність і потужність п’яти конкурентних сил 
(постачальники найбільш важливих ресурсів, покупці, конкуренція між продавцями всередині галузі, товари-субститути, потенційні продавці даного товару), масштаби діяльності конкурентів. Вибір маркетингової стратегії здійснюється в декілька етапів. Перш за все виявляються конкурентні переваги підприємств мережевих структур. Для оцінки можливостей успішного виходу компанії на ринок зіставляються дані аналізу зовнішнього та внутрішнього середовища i на їх основі проводиться порівняння характеристик даних підприємницьких структур, а також з очікуваннями споживачів та партнерів [2]. Підприємства мережевих структур визначають сильні та слабкі сторони, що допомагає ій виділити ті напрямки, в яких вони можуть досягти успіху; оцінюють можливості та загрози потенційних ринків, що допомагає визначити фактори, які $\epsilon$ необхідними для успіху на ринку. Порівняння потенційно успішних напрямків та важливих для успіху факторів дає підприємствам мережевих структур уявлення про власні конкурентні переваги та робить можливим розробку стратегій. Далі розробляється базова маркетингова стратегія - довгостроковий план підприємства мережевих структур, який повинен бути розписаним детально, тому що в будь-який момент може бути спростований будь-якими не передбаченими подіями у зовнішньому середовищі. Тому базова довгострокова стратегія не є чимось таким, що визначається раз і назавжди та ніколи не змінюється. Вона повинна регулярно коригуватися та уточнюватися в залежності від змін, які трапляються на ринку та результатів діяльності досліджуваних підприємств.

Відзначаємо, що існує три глобальних напрямки маркетингової стратегії, які використовуються у діяльності підприємств мережевих структур, а саме: сегментація, диверсифікація та інтернаціоналізація.

Стратегія сегментації - поглиблення ступені насичення товарами та послугами, що пропонуються всіх груп споживачів, вибір максимальної глибини ринкового попиту, вивчення найдрібніших його відтінків [8]. Завдяки сегментації, підприємства мережевих структур концентруються на вузькій сфері діяльності, та досягають скорочення витрат, що сприяє розширенню виробництва та дозволяє збільшити витрати на рекламу та заходи 3 просування товарів. Крім того, займаючи становищу лідера в обраному сегменті, компанія скорочує терміни окупності інвестицій. Слід зазначити, що єдиного методу сегментування ринку не існує. Підприємствам мережевих структур необхідно випробувати варіанти сегментування на основі різних змінних параметрів, одного чи декількох одразу, щоб відшукати найбільш корисний інноваційний підхід до розгляду структури ринку. Зазвичай ринки товарів споживчого призначення поділяють за:

- географічним принципом, який включає такі змінні як регіон, місто, клімат та ін;

- психографічним принципом; включає спосіб життя, суспільний клас тип особистості тощо;

- поведінковий принципом (отримані вигоди, привід для здійснення покупки, інтенсивність споживання, ступінь прихильності тощо);

- демографічним принципом (вік, стать, освіта, рівень доходів, розмір сім'ї тощо).

Неможливо залишити поза увагою те, що це тільки деякі критерії за якими проводиться сегментація ринку, для кожного ринку існує свій набір змінних, який може кардинально відрізнятися від наборів для інших ринків споживчих товарів, не кажучи вже про ринки товарів виробничого призначення.

Стратегія диверсифікації - освоєння виробництва нових товарів, товарних ринків, а також видів послуг, що включає не просто диверсифікацію товарних груп, але й розповсюдження підприємницької діяльності на нові та не пов'язані з основними видами діяльності підприємств мережевих структур [9]. В інших випадках, стратегія диверсифікації - це система заходів, що використовується для того, щоб мережеві структури не стали занадто залежним від одного стратегічного господарчого підрозділу чи однієї асортиментної групи. Вони передбачають розробку нових видів продукції одночасно з освоєнням нових ринків.

Основними стратегіями диверсифікації є: 
- стратегія концентрованої диверсифікації, яка базується на пошуку і використанні додаткових можливостей виробництва нових продуктів, що укладені в існуючому бізнесі; тобто існуюче виробництво залишається в центрі бізнесу, а нове виникає виходячи $з$ тих можливостей, що укладені в освоєному ринку, використаній технології або ж інших сильних сторонах функціонування фірми;

- стратегія горизонтальної диверсифікації припускає пошук можливостей росту на існуючому ринку за рахунок нової продукції, що вимагає нової технології, відмінної від використаної; за даної стратегії фірма повинна орієнтуватися на виробництво таких технологічно не зв'язаних продуктах, які б використовували вже наявні можливості фірми; тому що новий продукт має бути орієнтований на споживача основного продукту, по своїх якостях він має бути супутнім продуктам, що вже виробляються;

- стратегія конгломеративної диверсифікації полягає в тому, що фірма розширюється за рахунок виробництва технологічно не пов'язаних товарів, що реалізуються на нових ринках; це одна з найскладніших для реалізації стратегій розвитку; дуже часто ця стратегія реалізується шляхом придбання підприємств, а не створенням нових підприємств для роботи на новому ринку.

Стратегія інтернаціоналізації - освоєння нових, закордонних ринків, використовуючи не тільки розширення експорту товарів, але й експорту капіталів, коли закордоном створюються підприємства мережевих структур, що випускають в колишніх країнах-імпортерах товари, минаючи обмежувальні торгові бар'єри та використовуючи переваги дешевої робочої сили та багатої місцевої сировини. Організація міжнародної діяльності підприємств мережевих структур передбачає вибір способу виходу на міжнародні ринки. Вони можуть зупинитися на експорті, спільній підприємницькій діяльності чи прямому інвестуванні за кордоном. Кожний наступний стратегічний підхід потребує прийняття на себе більшого обсягу зобов'язань та більшого ризику, але обіцяє і більш високі прибутки [5].

Слід звернути увагу на те, що процес реалізації стратегії може бути розділений на два етапи: процес стратегічного планування - вироблення набору стратегій, від базової стратегії підприємств мережевих структур до функціональних стратегій та окремих проектів; процес стратегічного управління - реалізація певної стратегії в часі, переформулювання стратегії в світі нових обставин. На стадії стратегічного планування визначаються стратегії підприємств мережевих структур шляхом встановлення його місії, аналізу стратегічних позицій, дослідженню зовнішніх та внутрішніх факторів та дій, що можуть привести до досягнення, утримання, розвитку та капіталізації конкурентних переваг.

Відзначаємо, що підприємства мережевих структур змінюють стратегію в таких випадках: на протязі достатньо довгого часу вона не забезпечує досягнення задовільних показників; фірми-конкуренти різко змінили свою стратегію; змінилися інші зовнішні фактори для діяльності фірми; відкрилися перспективи для прийняття заходів, що в змозі значно підвищити прибутки фірми; змінились чи виникли нові переваги покупців, чи появились тенденції до можливих змін в цій галузі; поставлені в стратегії задачі вже вирішені та виконані.

Сучасним менеджерам необхідно ретельно аналізувати зовнішнє середовище для своєчасного внесення змін у вибраний напрям діяльності підприємств мережевих структур. Вони повинні добре знати особливості функціонування своєї мережевої структури, іiі сильні та слабкі сторони, щоб передбачити, які зміни принесуть успіх мережі. Вітчизняним підприємствам мережевих структур останні кілька років критичну ситуацію створюють динаміка ринку, яка важко прогнозується, безліч нових директивних рішень і законодавчих актів, зростання агресивності зовнішнього середовища, особливо у фінансовій сфері. Неможливо розробити ефективну 
маркетингову стратегію підприємствам мережевих структур, яка не визнає стратегічного планування взагалі. Адже стратегічно орієнтовані підприємства мережевих структур мають істотні переваги які при правильному використанні можуть зумовити вихід на лідируючі позиції в галузі. До таких переваг відносять:

- зменшення до мінімуму негативних наслідків змін, що відбуваються, а також факторів “невизначеності майбутнього”;

- можливість врахувати об’єктивні фактори, що формують зміни, зосередитись на вивченні цих факторів; сформувати відповідні інформаційні банки; рішень;

- можливість отримати необхідну базу для прийняття стратегічних і тактичних

- полегшити роботу по забезпеченню довго - та короткострокової ефективності та прибутковості;

- можливість зробити організацію більш керованою, оскільки за наявності системи стратегічних планів є змога порівнювати досягнуті результати з поставленими цілями, конкретизованими у вигляді планових завдань;

- можливість встановлення системи стимулювання для розвитку гнучкості та пристосованості організації та окремих ії підсистем до змін;

- забезпечення динамічності змін через прискорення практичних дій щодо реалізації стратегічних планів на основі відповідної системи регулювання, контролю та аналізу;

- створення виробничого потенціалу та системи зовнішніх зв'язків, що $\epsilon$ сприйнятливими до змін і дають можливість досягти майбутніх цілей;

- реалізація зазначених принципів дає змогу побудувати обгрунтовану послідовність дій щодо реалізації концепції та формування системи стратегічного управління [1, 185-187].

Висновки. Прорезюмувавши вище описане виявлено, що існуючі системи стратегічного управління підприємств мережевих структур не характеризуються чітко вираженою стратегічною спрямованістю, гнучкістю та адаптивністю. Отже, для створення дієвих систем стратегічного управління підприємствам необхідно враховувати означені імперативи розвитку і на цій основі розбудовувати механізми реалізації стратегії. До перспектив подальших досліджень слід віднести удосконалення методології кількісного прогнозування тенденцій трансформації сучасного бізнессередовища та планів стратегічного розвитку підприємств мережевих структур.

Відзначаємо, що 3 практичної точки зору мережева структура має наступні позитивні характеристики: децентралізація та мінімальна кількість рівнів управління; відсутність ієрархічного принципу; динамізм внутрішніх взаємодій; поширення стратегічного партнерства і договірних основ у горизонтальних зв'язках усередині мережі; зростання обсягів виробництва; економія затрат.

Підприємства мережевих структур забезпечують повноту дій, необхідних для досягнення поставлених цілей і погодженість зв'язків між усіма суб'єктами мережевої взаємодії; реалізує диференційований підхід до роботи, відповідно до чого мережі виступають як механізм інтеграційної політики. Все це визначає перспективність цієї форми організації підприємницької діяльності для вітчизняних підприємств.

\section{Список використаних джерел:}

1. Вівчар О. І. Особливості інноваційного маркетингу в Україні. Вісник Дніпропетровського університету. Науковий журнал. № 10/1. Том 19. Дніпропетровськ, 2011. С. 185-190.

2. Вівчар О. І., Колесніков А. П. Соціальна безпека. Навчальний посібник. Тернопіль: ФО-П Шпак В. Б., 2015. 146 с.

3. Гусєва О. Ю. Імперативи стратегічного управління торговельними підприємствами 3 урахуванням макротрендів бізнесу. Теоретичні і практичні аспекти економіки та інтелектуальної власності. 2015 Випуск 2(12). Том1. с.99105.

4. Ліщук В. І. Міжнародна передача технологій як інноваційний фактор економічного зростання. Економічна теорія та економічна історія. ЛДТУ. 2007. №4. С. 32-39. 
5. Питер Р. Диксон. Управление маркетингом. Навчальний посібник. Пер. с англ. - М.:ЗАЩ “Издательство БИНОМ”.1998. 232с.

6. Стельмащук А. М., Стельмащук Ю. А. Розвиток мережевих економічних систем як сервісний захід зростання масштабів ефективності виробництва інформаційні технології та економічна безпека. Науково-виробничий журнал «Інновачійна економіка». 3-4'2016 [62]. с.222-229

7. Шервуд Д. Системный подход для совершенствования бизнес-модели: Практика решения бизнеспроблем; Пер. с англ. - М.: Альпина Паблишер, 2016. 341 с.

8. http: // www/ expert. ua / articles /16/0/2130/.

9. http: // www. ConsultMarketing. ru.

УДК 658.6

Дейнега О.В., д.е.н., доцент, проректор з наукової роботи

Рівненський державний гуманітарний університет

\section{СПЕЦИФІКА МЕХАНІЗМУ ЗАДОВОЛЕННЯ ІНФОРМАЦІЙНИХ ПОТРЕБ ПРОМИСЛОВИМИ ПІДПРИЕМСТВАМИ НА РИНКУ В2В}

У статті ідентифікована суть інформаційних потреб індивідів та підприємств. Сформовано ієрархію інформаційних потреб підприємств, що базується на врахуванні рівня їх розвитку. Досліджено відмінності у структурі каналів отримання маркетингової інформації промисловими підприємствами на ринку В2В залежно від масштабів їх діяльності. Розглянуто ключові тенденції розвитку інформаційних послуг на світовому ринку В2В. Проаналізовано рівень задоволення інформаційних потреб промисловими підприємствами за рахунок застосування традиційних та електронних носіїв інформації. Розроблено рекомендації щодо засобів задоволення інформаційних потреб промисловими підприємствами різних масштабів діяльності.

Ключові слова: маркетинг, маркетингова інформація, ієрархія інформаційних потреб промислових підприємств, задоволення інформаційних потреб промислових підприємств, носії маркетингової інформації.

Deineha O.

\section{SPECIFICITY OF THE MECHANISM OF SATISFACTION OF INFORMATION NEEDS BY INDUSTRIAL ENTERPRISES IN THE B2B MARKET}

The article reveals the essence of the information needs of individuals and enterprises. Formed a hierarchy of information needs of enterprises, based on their level of development. The differences in the structure of channels for obtaining marketing information by industrial enterprises in the B2B market are investigated depending on the scale of their activities. The main directions of development of information services in the global B2B market are considered. The level of satisfaction of information needs of industrial enterprises through the use of traditional and electronic media is analyzed. Developed recommendations on how to meet the information needs of industrial enterprises of different scales of activity.

Key words: marketing, marketing information, hierarchy of information needs of industrial enterprises, satisfaction of information needs of industrial enterprises, carriers of marketing information.

Дейнега А.В.

\section{СПЕЦИФИКА МЕХАНИЗМА УДОВЛЕТВОРЕНИЯ ИНФОРМАЦИОННЫХ ПОТРЕБНОСТЕЙ ПРОМЫШЛЕННЫМИ ПРЕДПРИЯТИЯМИ НА РЫНКЕ В2В}

В статье раскрывается сущность информационных потребностей физических лиц и предприятий. Сформирована иерархия информационных потребностей предприятий, основанная на учете уровня их развития. Исследованы различия в структуре каналов получения маркетинговой информации промышленными предприятиями на рынке В2В в зависимости от масштабов их деятельности. Рассмотрены основные направления развития информационных услуг на мировом рынке В2В. Анализируется уровень удовлетворения информационных потребностей промышленных предприятий за счет использования традиционных и электронных средств информации. Разработаны рекомендации касательно средств удовлетворения информационных потребностей промышленных предприятий разных масштабов деятельности. 